5. Kostyuk AV (2014). Emotional intelligence and ways of its development. Scientific Bulletin of Kherson State University, (2), P. 85-89.

DOI https://doi.org/10.30525/978-9934-26-073-5-2-78

\title{
МАТЕРІАЛИ ТЕD ТАLКS ЯК ДОДАТКОВИЙ ЗАСІБ НАВЧАННЯ ІНОЗЕМНОЇ МОВИ В СТАРШИХ КЛАСАХ ЗАКЛАДІВ ОСВІТИ
}

\author{
Шпак Т. С. \\ учитель англійської мови \\ Харківського лічуею № 141 \\ м. Харків, Украӥна
}

На теперішньому етапі свого розвитку українське суспільство зіткнулося 3 рядом важливих та нагальних викликів у різних сферах життя, які потребують якісного вирішення - це і активні євроінтеграційні процеси, інформатизація населення, і життя в умовах пандемії, тощо. А сучасний освітній простір один із тих, який потребує реформування та швидкого реагування на нагальні проблеми в таких непростих умовах. Слід також зауважити, що відповідно до засад розвитку освіти в України у XXI столітті іншомовна освіта знаходиться в центрі уваги реформаційних процесів освітньої сфери та $є$ одним із важливих складників сучасного освітнього процесу в закладах освіти. Сучасна мовна політика та проблеми в галузі вивчення та навчання іноземної мови як одного із засобів міжкультурного спілкування вимагають сучасних та інноваційних підходів до методики викладання, якісного удосконалення професійної та іншомовної комунікативної компетенції сучасних учителів, імплементації в навчальний процес сучасних засобів та технологій навчання.

Одним із таких засобів $є$ використання інформаційних та мультимедійних технологій у роботі з учнями на уроках іноземної мови, які відкривають нові можливості впровадження в освітній процес нових методів і прийомів навчання. Послуговуючись Концепцією нової української школи (2016) зазначимо, що використання інформаційних та мультимедійних технологій в освітній галузі має перейти від періодичного застосування в системний характер. Такі технології значною мірою розширюють спектр можливостей освітянина, оптимізують навчальні процеси, формуючи необхідні для сьогодення компетенції [1]. Парадигма інформаційних та мультимедійних засобів 
навчання включає цілу низку інструментів, наприклад: електронні тренажери, презентації, аудіо- та відеоматеріали, навчальні сайти, електронні навчальні видання, ресурси мережі Інтернет тощо

У світлі нашої розвідки та спираючись на відповідні методичні розробки (наприклад: [3; 5] та ін.) вважаємо, що одним із дієвих засобів навчання іноземної мови $є$ використання автентитичних відеоматеріалів. Не зайвим буде акцентувати увагу і на тому, що сучасні наукові праці в галузі психології та методики навчання іноземної мови також наголошують на доцільності використання таких матеріалів, оскільки вони поєднують у собі аудіальний та візуальний канали сприйняття інформації.

Одним із зручних та ефективних мультимедійних ресурсів, який можна використовувати під час навчання іноземної мови, може послугувати проєкт TED Talks, який надає можливість для всіх бажаючих ознайомитися із відеозаписами ідеаційних промов спікерів на різну тематику, які характеризуються чіткою логікою побудови промови, зрозумілими та змістовними реченнями, яскравими лексичними одиницями, зрозумілою вимовою мовця тощо. Додатковою перевагою $є$ і те що, що при використанні такого матеріалу в учня $\epsilon$ можливість декілька разів ознайомитись 3 відео-матеріалом, повернутися до незрозумілих місць, навчатися у зручний час та місці, де є вихід до мережі Інтернет, взаємодіяти з іншими користувачами під час обговорення, у тому числі і з іноземними, у разі потреби використати субтитри або текстовий варіант промови (transcript). Ще однією прикметною особливістю матеріалів проєкту TED Talks - $\epsilon$ те, що теми, які порушують у своїх виступах спікери стимулюють у сучасного покоління зацікавленість, розширюють світогляд, дають загальне уявлення про стан сучасної науки та технологій, надають більш глибоку інформацію про різноманітні сфери сучасного життя в різних куточках світу, що в свою чергу заохочує сучасного школяра до вивчення нового та допомагає отримувати задоволення від навчання. Усе це надає вчителеві іноземної мови можливість використовувати подібні матеріали як додатковий ефективний засіб навчання та розвитку іншомовної комунікативної компетенції.

Ефективним у формуванні англомовної комунікативної компетенції $\epsilon$ використання автентичних матеріалів i запропонована до розгляду платформа дозволяє учням взаємодіяти саме з таким матеріалом, почути різні варіанти вимови та акцентів, спеціальну лексику, спостерігати на практиці функціонування різних граматичних структур та всебічно розвиває сприйняття усного англомовного мовлення. 
Для вчителя важливими $\epsilon$ i аспекти відбору відеоматеріалів, адже потрібно враховувати рівень володіння учнями іноземною мовою, матеріал повинен відповідати цілям та завданням уроку, необхідно враховувати вікові особливості школяра, їхні інтереси та пам'ятати про те, що такий вид роботи повинен обмежуватися певним часовим регламентом, оскільки протягом довгого перегляду увага учнів часто може втрачатися (а матеріали, які пропонує платформа TED Talks є хронологічно прийнятними для цього). Окрім цього, учитель повинен доцільно використовувати подібний матеріал у свої роботи та грамотно вибудовувати алгоритм роботи 3 ним. Так, наприклад, відібравши прийнятний за учнівським рівнем мовної підготовки відеофрагмент, необхідно розробити ряд вправ, які послугують основою та опорою для засвоєння учнями нового матеріалу та знань. Традиційно робота 3 відеоматерілом передбачає три етапи: 1) переддемонстраційний, 2) демонстраційний та 3) післядемонстраціний [3]. Коротко розглянемо процес реалізації кожного з них:

1) Мета першого етапу - активізація знань учнів, налаштування на роботу з матеріалом, викликати в учнів зацікавленість. Робота на цьому етапі може бути спрямована на роботу з вокабуляром, який допоможе забезпечити розуміння матеріалу. Так, для знайомства 3 новою лексикою можна запропонувати учням список слів з їхніми дефініціями або вправи на відповідність лексичної одиниці та їі визначення, підбір синонімів, заповнення пропусків у тексті тощо. Приклад такого завдання: «Before watching the video, match the following phrases with synonyms».

2) Основний - демонстраційний - етап роботи 3 відеофрагментом може передбачати розуміння або конспектування змісту почутого. Так, наприклад, учні можуть занотовувати основні думки та фрази мовця, його ідеї, статистичні дані, що стосуються промови. Для концентрації уваги учнів на основних моментах промови вчителеві заздалегідь необхідно запропонувати ряд положень або питань, які акцентують увагу учнів на необхідних аспектах промови. Корисною також може бути вправа на заповнення пропусків, наприклад, у текстовому варіанті промови. Подібна вправа може всебічно сприяти запам'ятовуванню лексичних одиниць, адже учень не тільки вчиться сприймати одиницю на слух, а й запам'ятовує їі написання, бачить оригінальний контекст їі використання.

3) На фінальному - післядемонстраційному - етапі може бути організована дискусія, під час якої учні можуть обговорити запропоновану проблемну тему, яка пов'язана 3 прослуханим виступом, висловити власні думки про почуте тощо. 
Отже, зазначимо, що проєкт TED Talks та його матеріали - це потужній інструмент, який може якісно та змістовно урізноманітнити освітній процес, стати помічником у практичному формуванні та розвитку іншомовної комунікативної компетенції, зацікавити школярів тематикою виступів. До переваг таких матеріалів можна зарахувати їхню загальну доступність, автентичність, високу якість контенту; а тематична різноплановість виступів спікерів дозволяє учителеві підібрати матеріал відповідно до теми уроку (загальної тематики, спеціальної тощо); у свою чергу робота учнів 3 такими матеріалом надає можливості для покращення навичок аудіювання, роботи 3 фонетичною системою мови, постави вимови, розширення словникового запасу, критичного осмислення почутого, розвитку навичок як монологічного, так і діалогічного мовлення, які вкрай важливі для комунікації в сучасному полікультурному та полілінгвальному світі. Отже, матеріали проєкту TED Talks можуть послугувати додатковим ефективним автентичним засобом побудови навчального процесу, особливо в умовах дистанційної освіти (або змішаного формату навчання), мотивувати здобувачів старшої школи до навчання, пізнавальної діяльності, співпраці, спілкування та критичної оцінки світу.

\section{Література:}

1. Нова українська школа. Концептуальні засади реформування середньої школи [Електронний ресурс] / за заг. ред. М. Грищенка; МОН України. Київ: MOH України, 2016. 40 c. URL: https://mon.gov.ua/storage/ app/media/zagalna\%20serednya/nova-ukrainska-shkola-compressed.pdf (Дата звернення: 15.04.2021)

2. Фещенко О. Процес застосування інформаційно-комунікативних технологій на уроках англійської мови під час формування мовленнєвих навичок. Молодий вчений. 2020. № 9(85). С. 229-231.

3. Altman R. The video connection: Integrating video into language teaching. Boston: Houghton Mifflin, 1989. 184 p.

4. Ciornei S., Dina A.T. Authentic texts in teaching English. Procedia Social and Behavioral Sciences. 2015. Vol. 180. P. 274-279.

5. Wember V., Buchynska D. Modern types of educational video and features of their use in the educational process. Educational Discourse. 2016. № 1(13). P. 19-27. 